\title{
Analysis of the Impact of the Fireplace Heating on the Energy Performance of the Family House
}

\author{
Rastislav Ingeli ${ }^{1 *}$, Peter Buday ${ }^{1}$ \\ ${ }^{1}$ Department of Building Structures, Faculty of Civil Engineering, Slovak University of Technology, Radlinského 11, \\ 81005 Bratislava, Slovak Republic \\ * Corresponding author, e-mail: ingeli@ehb.sk
}

Received: 17 September 2019, Accepted: 18 December 2019, Published online: 13 March 2020

\begin{abstract}
Reduction of energy use in buildings is an important measure to achieve climate changes of mitigation. It is essential to minimize heat losses when designing energy efficient buildings. For energy efficient building in a cold climate, a large part of the space heating demand is caused by transmission losses through the building envelope. In compliance with the today's trend of designing sustainable and energy-saving architecture, it is necessary firstly to solve the factors influencing the energy balance. This year the subsidy for houses has been valued at $€ 8,000$. The condition is that the building is classified in the energy class A0 according to the Energy Performance Act. Energy class A0 characterizes nearly zero energy buildings. The main concern is for the public to become interested in such buildings. The subsidy is designed to reward and promote those buildings that their heat and technical characteristics and modern technical equipment that meet energy class. In addition to a good plan to raise the profile of such buildings, there has been a lot of speculation to help make buildings in energy class A0. They are mainly owners of family houses where there is no gasification and are forced to have electricity as a source of heat and hot water. Electricity has a high primary energy factor, which means that buildings do not have to be approved.
\end{abstract}

Keywords

fireplace heating, energy efficiency of buildings, building energy class, flow simulation

\section{Introduction}

Act no. 300/2012 Coll. [1] stipulates that from 1.1.2021 all buildings need to be designed with nearly zero consumption [2, 3]. A near-zero energy building is classified as energy class A0 for the global indicator of primary energy in terms of the energy performance of buildings. To achieve this category of buildings it is necessary to improve the envelope from the heat-technical point of view. To find an optimal solution that will ensure a balance between the costs of progressive materials, technical equipment of buildings and overall reduced energy intensity. One of the factors is the configuration of the envelope on which the energy savings depend. Significant impact on thermal protection envelope has a lot of factors. For example, envelope accumulation [4], moisture properties, thermal bridges [5], the use of passive solar gains [6]. In addition to thermal properties of building envelope, which is part of the thermal protection of buildings has a significant impact on energy class of residential buildings and the selected source of heat for heating and hot water.
In this paper we analyze a fireplace equipment impact on the energy performance of the building and particularlyan impact on the energy class in a selected family house. During analyzing we combine different heat sources and we monitor their impact on the global indicator.

\subsection{Description of analyzed family house - bungalow}

For the analysis a family house with one residential floor and garage was selected. The ground plan of the house is $18.5 \times 8.5 \mathrm{~m}$ and the specific area is $123 \mathrm{~m}^{2}$, the built-up volume is $390 \mathrm{~m}^{3}$, the average height of the heated floors is $3.17 \mathrm{~m}$ and the building shape factor is $1.001 / \mathrm{m}$. The garage is not included in the total measuring area, as it is a space only with temperature control and not a full-fledged heating. The shape and layout of the building reflects the current demand of simple and modern buildings. The individual packaging structures (ceiling, perimeter wall, floor on the ground and transparent structures) were designed from the thermo-technical point of view 
so that they meet the criterion of recommended values, which are set in the standard STN 73 0540-2: 2012 [7]. The heat transfer coefficient of the ceiling under the loft, walls, openings and the floor on the ground is calculated according to the actual built-in materials. The ceiling under the loft is defined $U=0.14 \mathrm{~W} /\left(\mathrm{m}^{2} \mathrm{~K}\right)$, the perimeter wall $U=0.180 \mathrm{~W} /\left(\mathrm{m}^{2} \mathrm{~K}\right)$, transparent structures $U=0.80$ to $0.99 \mathrm{~W} /\left(\mathrm{m}^{2} \mathrm{~K}\right)$ (depending on the proportion of the values of the glazing $U_{g}=0.60$ and the frame $\left.U_{f}=1.10 \mathrm{~W} /\left(\mathrm{m}^{2} \mathrm{~K}\right)\right)$ [8]. The thermal resistance of the floor on the terrain is given by the $R$ value of the floor is $2.63 \mathrm{~m}^{2} \mathrm{~K} / \mathrm{W}$ (after conversion $U=0.220 \mathrm{~W} /\left(\mathrm{m}^{2} \mathrm{~K}\right)$ ). The total solar transmittance of the used triple glazing is given by the value of $g=0.5$. Thermal bridges are counted as a flat rate value and the standard value is $\Delta U=0.02 \mathrm{~W} /\left(\mathrm{m}^{2} \mathrm{~K}\right)[9]$. The analyzed house is shown in the following figures (Figs. 1 and 2).

\subsection{Calculation of the heat demand for different variants}

Calculation of the heat demand for heating in the analyzed building was determined for two variants. The first variant is characterized by the need to heat the heating without

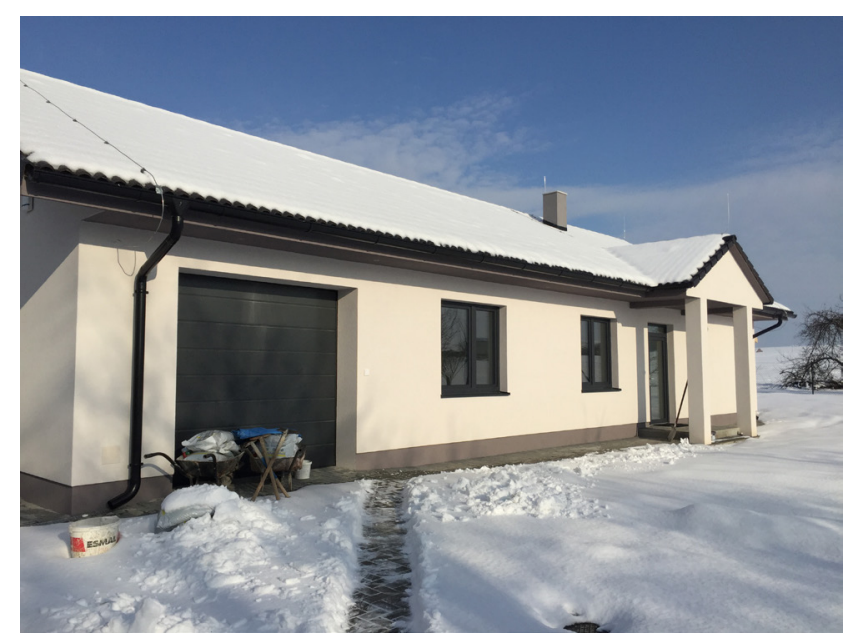

Fig. 1 A real view of the house

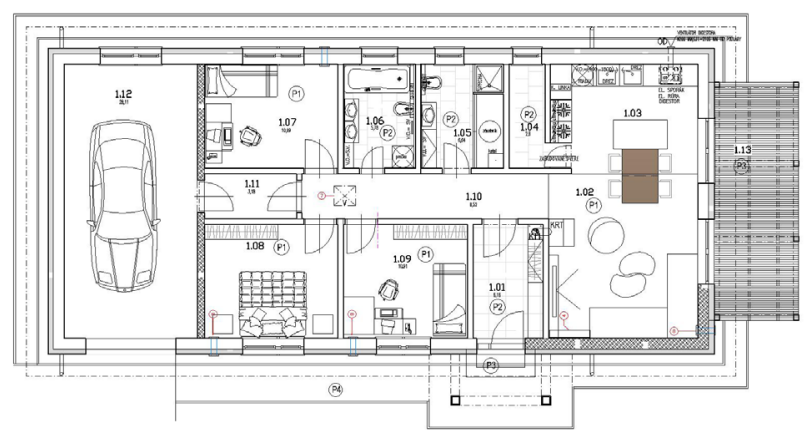

Fig. 2 Geometry and layout of analyzed family house considering ventilation with heat recovery air and the other option considered ventilation with heat recovery and air with $95 \%$ efficiency heat recovery equipment [10]. Table 1 shows complex results for both variants. As it can be seen from Table 1, the calculated heat demand for variant no. 2 (variant with recuperation) is almost $50 \%$ smaller than for variant no. 1 (variant without heat recovery).

\section{Assessing the energy performance of buildings}

In the analyzed family house, underfloor heating with a wet system is realized. The individual branches of the underfloor heating circuits are connected via a zone-controlled distributor for each room in the house. The Beretta Exclusive Green condensing boiler is the heat source. The standard utilization rate is $102 \%$. Installed electric power is $67 \mathrm{~W} / 230 \mathrm{~V}$. The equithermal regulation of the boiler is solved. The hot water is prepared in the Dražice storage tank with a capacity of 125 liters installed under the boiler.

\subsection{Classification of the house into the energy class}

Every building that has been approved has to submit an energy certificate of the building. The analyzed family house was classified into the energy class according to the real values and the real geometry of the building. The global primary energy indicator is for the family house in energy class A1. That in this case means that such object is not entitled to remuneration in the form of a subsidy of $€ 8000$. There are many such cases and the question arises in what form this subsidy can be obtained and what forms of adjustment can be applied to the object. Many homeowners consider the idea of having a solid fuel source such as a fireplace, stove, or other in a building to reach the A0 primary energy class. Therefore, Table 2 shows the analysis using the fireplace body placed in the building and in the living room. The calculation is divided according to the percentage use of the fireplace for the energy need for heating. The distribution is for $30 \%$ use

Table 1 A comprehensive overview for both variants

\begin{tabular}{lccc}
\hline Variant & Variant & Variant & \\
& -1 & -2 & \\
\hline Total heat exchange area & 390 & 390 & $\mathrm{~m}^{2}$ \\
Heat loss of heat transfer & 87.85 & 87.85 & $\mathrm{~W} / \mathrm{K}$ \\
Ventilation heat loss & 51.48 & 4.37 & $\mathrm{~W} / \mathrm{K}$ \\
Total heat loss & 147.13 & 100.02 & $\mathrm{~W} / \mathrm{K}$ \\
Total gains & 3825.3 & 3825.3 & $\mathrm{kWh}$ \\
Energy need for heating & 8371.3 & 4577.2 & $\mathrm{kWh} / \mathrm{a}$ \\
Specific heat energy demand $Q_{H, n d 1}$ & 68.06 & 37.21 & $\mathrm{kWh} / \mathrm{m}^{2} \mathrm{a}$ \\
\hline
\end{tabular}


Table 2 Classificationof individual variants into the energy class

\begin{tabular}{|c|c|c|c|c|c|c|c|}
\hline Variant & $\begin{array}{l}\text { Air } \\
\text { recovery }\end{array}$ & $\begin{array}{l}\text { Energy for heating } \\
\text { in } \mathrm{kWh} / \mathrm{m}^{2} \mathrm{a}\end{array}$ & $\begin{array}{l}\text { Description of the heat } \\
\text { source for heating and the } \\
\text { proportion of use }\end{array}$ & $\begin{array}{l}\text { Energy need for heating } \\
\text { in } \mathrm{kWh} / \mathrm{m}^{2} \mathrm{a}\end{array}$ & $\begin{array}{l}\text { Energy use for hot water } \\
\text { in } \mathrm{kWh} / \mathrm{m}^{2} \mathrm{a}\end{array}$ & $\begin{array}{l}\text { Primary } \\
\text { energy }\end{array}$ & $\begin{array}{c}\text { Energy } \\
\text { class }\end{array}$ \\
\hline V_1A & No & 68.06 & Gas $-100 \%$ & 71.6 & 19.9 & 100.7 & A1 \\
\hline $\mathrm{V} \_2 \mathrm{~A}$ & Yes & 37.21 & Gas $-100 \%$ & 39.2 & 19.9 & 65 & A1 \\
\hline V_1B & No & 68.06 & $\begin{array}{c}\text { Gas }-70 \% \\
\text { Wood }-30 \%\end{array}$ & 79.3 & 19.9 & 77.6 & A1 \\
\hline V_2B & Yes * & 37.21 & $\begin{array}{c}\text { Gas }-70 \% \\
\text { Wood }-30 \%\end{array}$ & 43.4 & 19.9 & 52.4 & A0 \\
\hline V_1C & No & 68.06 & $\begin{array}{c}\text { Gas }-50 \% \\
\text { Wood }-50 \%\end{array}$ & 84.4 & 19.9 & 62.3 & A1 \\
\hline V_2C & Yes * & 37.21 & $\begin{array}{c}\text { Gas }-50 \% \\
\text { Wood }-50 \%\end{array}$ & 46.2 & 19.9 & 44.0 & A0 \\
\hline V_1D & No & 68.06 & $\begin{array}{c}\text { Gas }-0 \% \\
\text { Wood }-100 \%\end{array}$ & 97.2 & 19.9 & 23.8 & A0 \\
\hline V_2D & Yes & 37.21 & $\begin{array}{c}\text { Gas }-0 \% \\
\text { Wood }-100 \%\end{array}$ & 53.2 & 19.9 & 23.0 & A0 \\
\hline
\end{tabular}

* We do not consider that air recovery and air distribution will mix the air from the living room and distribute it to the building

of the fireplace, which means heating only for the living room. Furthermore, for $50 \%$ use of the fireplace, this means heating of the living room and hallway. And the last one for full, $100 \%$ use of the fireplace body, which means heating of the whole house with this fireplace.

\subsection{Simulation analysis of the fireplace in the analyzed family house - FLOVENT}

Table 2 shows that if we consider the need for energy to heat a fireplace, we can reach the energy class $\mathrm{A} 0$ for the given object. This means that if the object had a fireplace, it could get a state subsidy. The question is, whether it is possible to heat the whole building with a fireplace without hot air distribution. Since it is most speculative in practice to use a fireplace without hot air distribution as the primary source, this case was simulated using the CFD program. Figs. 3 and 4 show a family house model in CFD [11]. Figs. 5 and 6 show the temperature distribution for a given object in two variants. A variant is considering building heating by the fireplace located in the living room (output $5.75 \mathrm{~kW}$ ) and open interior doors in all rooms. Variant B considers the closed interior doors in the whole building.

The air exchange considered is 0.5 in both variants. The range of temperatures in each zone is shown in Figs. 5 and 6.

Figs. 7 and 8 show the interaction of internal temperatures for individual rooms of the family house.

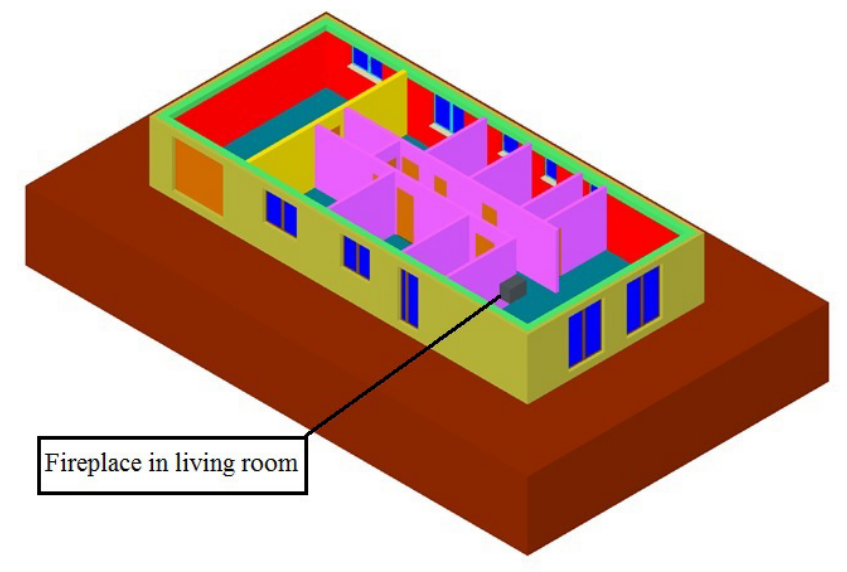

Fig. 3 3D model of analyzed family house

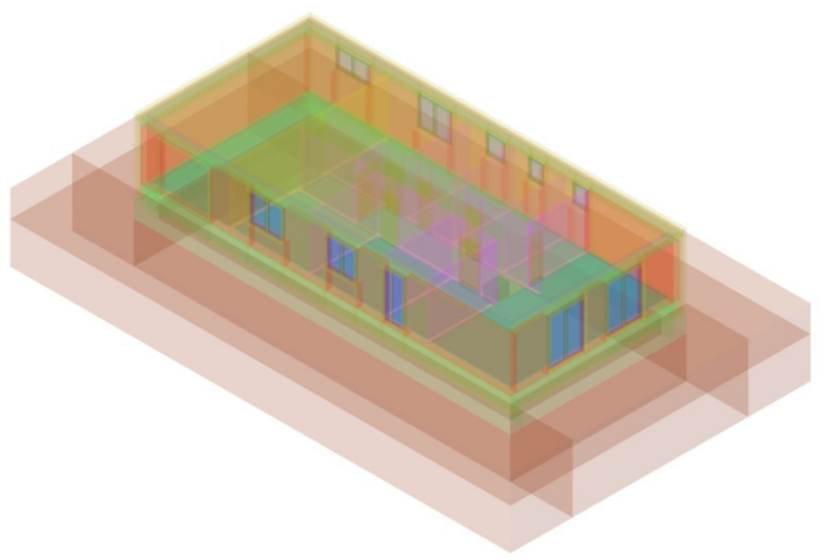

Fig. 4 Zone division in CFD 


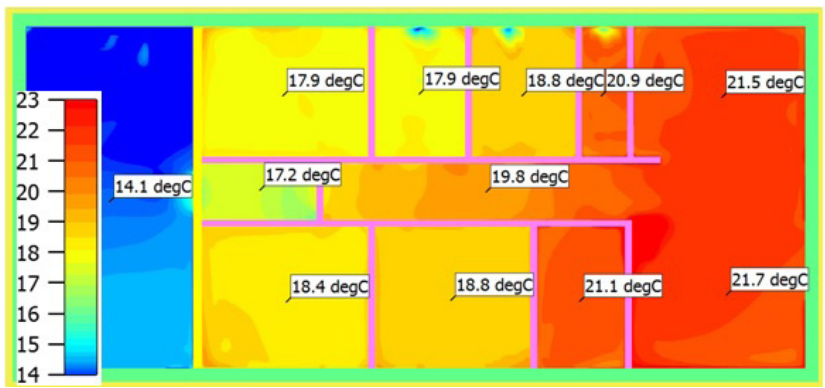

Fig. 5 Outputs from CFD simulation of family house - variant A (open interior doors in all rooms)

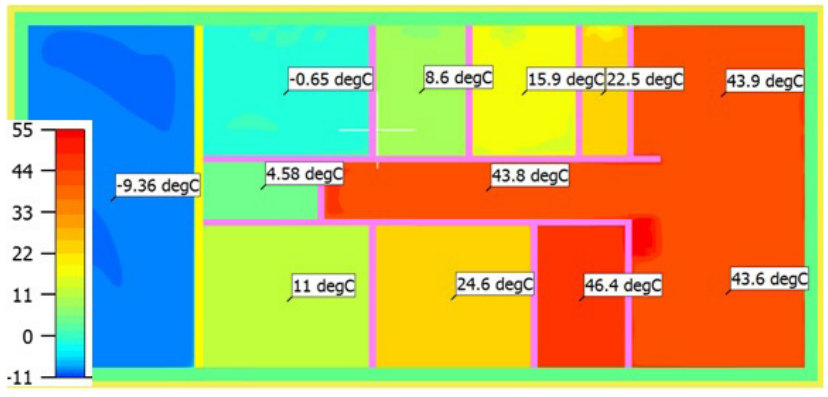

Fig. 6 Outputs from CFD simulation of family house - variant B (closed interior doors in all rooms)

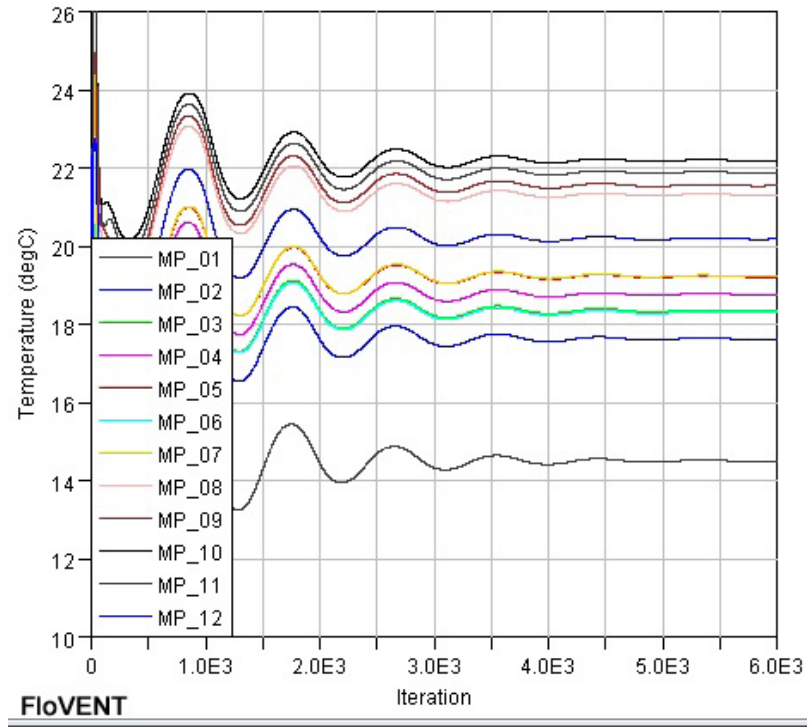

Fig. 7 Iteration of indoor temperature in individual rooms - variant A (open interior doors in all rooms)

Figs. 9 and 10 show the interaction of pressure for individual rooms of the family house.

The calculation is made for the standard winter boundary condition of $-11^{\circ} \mathrm{C}$. The temperature of the soil is $+5{ }^{\circ} \mathrm{C}$. Figs. 7 to 10 are iterative calculations of temperature and pressure variables at selected points (air) across a building defined horizontally and vertically. Iteration

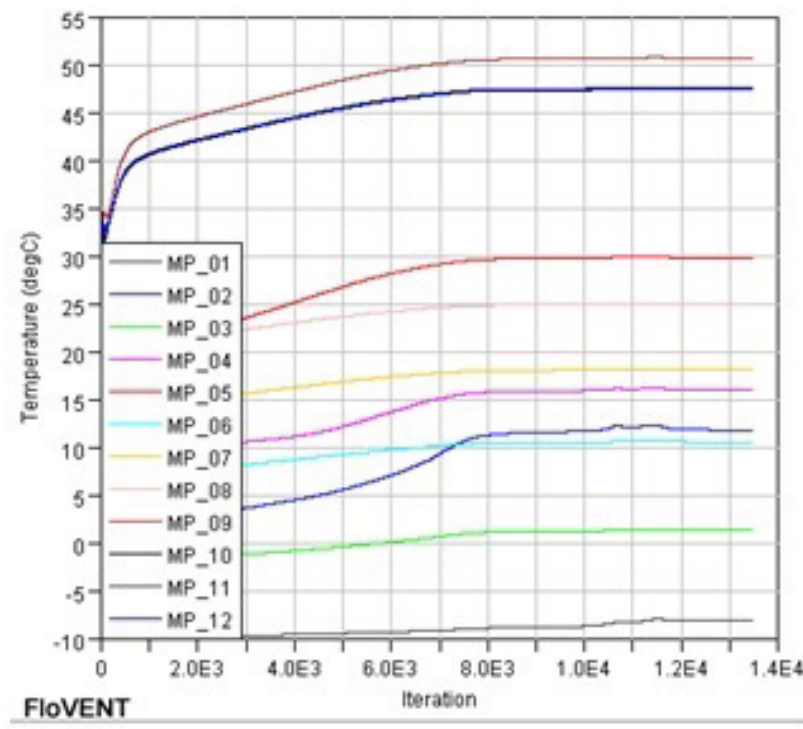

Fig. 8 Iteration of indoor temperature in individual rooms - variant B (closed interior doors in all rooms)

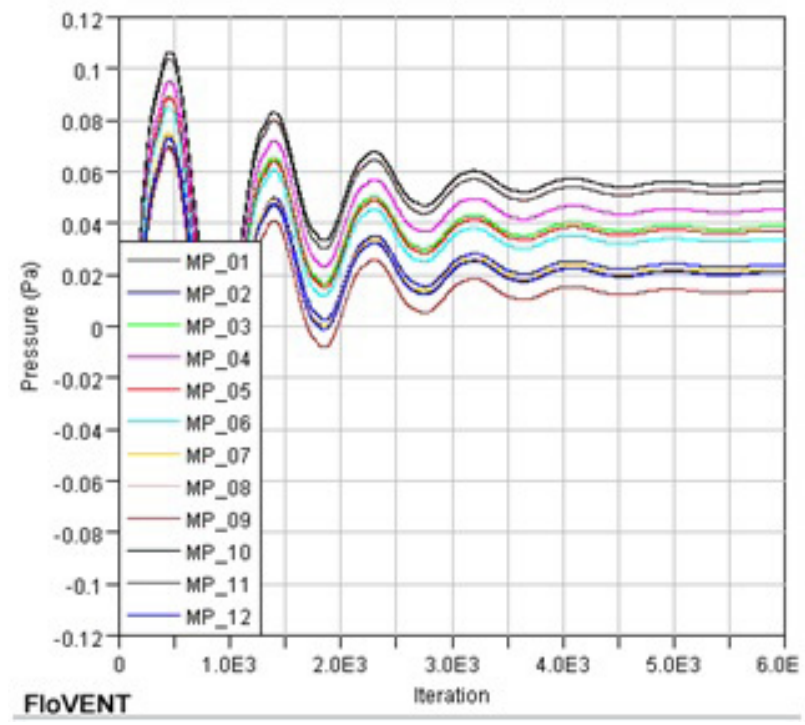

Fig. 9 Iteration of pressure in individual rooms - variant A (open interior doors in all rooms)

in computing is the technique marking out of a block of statements within a computer program for a defined number of repetitions. Another use of iteration in mathematics is in iterative methods that are used to create approximate numerical solutions to certain mathematical problems.

\section{Conclusions}

As can be seen from the previous results, considering the fireplace in energy classification has a significant impact on the global indicator - primary energy. As you can see from the temperature distribution in the house, it is 


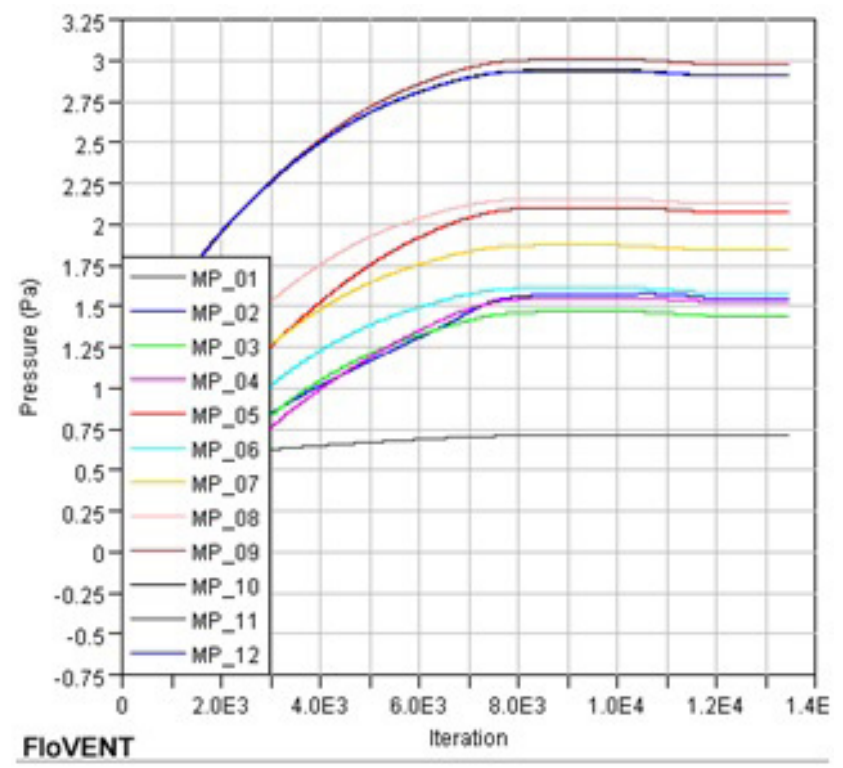

Fig. 10 Iteration of pressure in individual rooms - variant B (closed interior doors in all rooms)

\section{References}

[1] Act no. 300/2012. "Amending and supplementing Act no. 555/2005 on the energy performance of buildings and on amendments to certain acts, as amended, and amending and supplementing Act no. 50/1976 on land-use planning and building code (Building Act), as amended", Bratislava, Slovakia, 2012.

[2] Ingeli, R., Čekon, M. "Analysis of Energy Consumption in Building with NZEB Concept", Applied Mechanics and Materials, 824, pp. 347-354, 2016.

https://doi.org/10.4028/www.scientific.net/AMM.824.347

[3] Ingeli, R. "Analysis of Alternative Energy Sources in Building with NZEB Concept", In: Advanced Building Construction and Materials 2016 (ABCM 2016), Luhačovice, Czech Republic, 2016, pp. 347-354.

[4] Oravec, P. "Analysis of a Family House on the Basis of Wood After 35 Years of Use", In: Geoconference on Nano, Bio and Green Technologies for a Sustainable Future, Albena, Bulgaria, vol. 2, 2014, pp. 27-32.

https://doi.org/10.5593/SGEM2014/B62/S26.004

[5] Juras, P. "Comparison of triple glazed windows based on longterm measurement", IOP Conference Series: Materials Science and Engineering, 415, Article number: 012020, 2018. https://doi.org/10.1088/1757-899X/415/1/012020

[6] Katunský, D., Zozulák, M., Lopušniak, M., Bagoňa, M., Katunská, J. "External brick wall and window detail in test cell in winter", International Journal of Civil Engineering and Technology, 9(4), pp. 1654-1663, 2018. not possible to consider a fireplace as a primary heat source without hot air distribution. Quite often this variant is real but unsuitable in practice, especially when there is electric heating in the building. Electric heating has a significant impact on emissions production and on the increase of primary energy. The results indicate that there is a lack of legislative guidance for considering the fireplace in energy certification and classification into energy class.

\section{Acknowledgement}

The project presented in this article is supported by the Research and Development Agency no. APVV - 16-0126.

[7] Building Testing and Research (TSUS) "STN 73 0540-2 2012 Thermal protection of buildings. Thermal performance of buildings and components. Part 2: Functional requirements", Slovak Office of Standards, Metrology And Testing (SUTN), Bratislava, Slovak Republic, 2012.

[8] Chmúrny, I. "Triple or Quadruple Glazing?", Applied Mechanics and Materials, 820, pp. 242-247, 2016.

https://doi.org/10.4028/www.scientific.net/AMM.820.242

[9] Ingeli, R., Podhorec, J., Čekon, M. "Thermal Bridges Impact on Energy Need for Heating in Low Energy Wooden House", In: Applied Mechanics and Materials, 820, pp. 139-145, 2016. https://doi.org/10.4028/www.scientific.net/AMM.820.139

[10] Jankovichová, E., Ingeli, R., Nguyen Tien, M. "Technical and Economical Solution of Using the Renewable Energy", In: International Scientific Conference on Construction Technology and Management (CTM 2014), Bratislava, Slovakia, 2014, pp. 525-533.

[11] FloVENT® 10.1 "Optimize HVAC airflows with fast, easy-touse and industry-proven CFD simulation", [online] Available at: www.mentor.com/https://www.mentor.com/products/mechanical/ flovent/ [Accessed: 07 December 2019] 